medium containing $1 \times 10^{-7} \mathrm{M}{ }^{3} \mathrm{H}$-oulabain (New England Nuclear Corporation) for $1 \mathrm{hr}$ at $37^{\circ} \mathrm{C}$. The specific uptake on the pump site and the number of these sites were calculated using the procedure of Baker and Willis (9). The binding number per cell was $2.7 \times 10^{5}$ molecules for RHR cells and $2.2 \times 10^{5}$ for RHS cells. The number of Na pump sites in RHR cells did not differ greatly from that of RHS cells. The Na pump inhibited by ouabain, is apparently not related primarily to the osmoregulatory mechanisms in RHR cells.

Acknowledgements: Thanks are due to Dr. F. Sakai for pertinent advice and encouragement. This work was supported by research grants from the Ministry of Education, Science and Culture, Japan, and Foundation for the Promotion of Research on Medicinal Resources.

\title{
REFERENCES
}

1) Sato, A., Ozawa, K. And Jtoh, H.: Japan. J. Pharmacol. 22, 104 (1972); 2) Whittam, R. and Wheller, K.P.: A. Rev. Physiol. 32, 21 (1970); 3) Katsuta, H.: Tissue Culture Technic, p. 107, Tokyo, Japan (1955); 4) Palmer, R.F. ANd Nechay, B.R.: J. Pharmacol. exp. Ther. 146, 92 (1964); 5) LfF, K.S. and Yu, D.H.: Biochem. Pharncicol. 12, 1253 (1963); 6) Burrows, R. And Lamb, J.F.: J. Physiol, 162, 510 (1962); 7) Nelson, J.A. And Nechay, B.R.: Pharmacologist 12, 240 (1970); 8) LAMB, J.F. AND MACKINNon, M.G.A.: J. Physiol. 213, 665 (1971); 9) Baker, P.F. ANd Wil.t.s, J.S.: J. Pigysiol. 224, 441 (1972)

\section{HYDROLYSIS OF BRADYKININ BY STEM BROMELAIN}

\author{
Satoru MINESHITA and Yutaka NAGAI* \\ Department of Clinical Pharmacology and $*$ Department of Tissue Physiology, \\ Medica! Research Institute, Tokyo Medicat and Dental University, \\ Chiyoda-ku, Tokyo 101, Japan
}

Accepted September 28, 1976

During the course of studies on the anti-cdema and anti-inflammatory actions of stem bromelain, a potent kininase activity was observed (1). The present paper describes the analysis of the bonds of bradykinin which are susceptible to the action of stem bromelain.

Twelve milligrams (12/moles) of synthetic bradykinin (Protein Research Foundation, Minoh, Osaka) dissolved in $3 \mathrm{ml}$ of $5 \mathrm{mM}$ phosphate buffer, pH 7.5, containing $2 \mathrm{mM} \beta-$ mercaptoethanol, was mixed with $3 \mathrm{ml}$ of purified stem bromelain ( $7.2 \mathrm{mg}: 0.218$, preincubated in the same buffer at $37^{\circ} \mathrm{C}$ for $20 \mathrm{~min}$ for full activation. Twenty microliter aliquots of the reaction mixture incubated at $37^{\circ} \mathrm{C}$ were withdrawn every $5 \mathrm{~min}$ for assay of rat utcrus smooth muscle contracting activity. The contracting activity decreased to $0.5 \%$ of the original after $15 \mathrm{~min}$ incubation. The resultant reaction mixture was stored at $-20^{\circ} \mathrm{C}$ until required. Enzyme solution without added bradykinin was treated in parallel as control. An aliquot of the reaction mixture was heated in a boiling water bath for 10 min to inactivate the enzyme and dinitrophenylated at $\mathrm{pH} 9.0$ at $40^{\circ} \mathrm{C}$ in the dark for $2 \mathrm{hr}(2)$. The DNPderivatives were separated into ether-soluble and aqueous fractions by extracting with 
peroxide-free ether at acidic $\mathrm{pH}$. The $\mathrm{N}$-terminal amino acid residues, analyzed by paper chromatography after hydrolysis with $6 \mathrm{M} \mathrm{HCl}$ at $100^{\circ} \mathrm{C}$ for $12 \mathrm{hr}(2)$, were found to be phenylalanine and serine in a molar ratio of about 1 to 6 in the ether soluble fraction, based on the measurements of absorbance of eluted DNP-amino acids at $360 \mathrm{~nm}$. Only arginine was identified as $\mathrm{N}$-terminal residue in the aqueous fraction. No appreciable amount of free arginine was obtained in the aqueous fraction by paper chromatography with t-amylalcohol solvent system at $\mathrm{pH} 6$ and by paper electrophoresis with pyridine-formic acid buffer systems, before acid hydrolysis. Since DNP-Pro is labile under the conditions of hydrolysis, absorbance of DNP-derivatives in both fractions was determined at $390 \mathrm{~nm}$ and $360 \mathrm{~nm}$ prior to acid hydrolysis. No indication of the presence of $\mathrm{N}$-terminal proline was obtained from the ratio of the absorbances at these wave lengths (3).

Another aliquot of the reaction mixture was submitted to Amberlite CG-50 chromatography $(0.9 \times 30 \mathrm{~cm}$ column). Elution was with a linear gradient of $\mathrm{NaCl}(0.05 \mathrm{M}$ to $2 \mathrm{M})$ in $0.2 \mathrm{M}$ borate buffer, pH 7.0. Four major and three minor peaks were obtained using the ninhydrin and Sakaguchi reagents for detection (4). The first peak (tube Nos. 6-8) was found to be Sakaguchi-negative. Amino acid analysis of the peaks (Table 1) revealed that the first peak was composed of phenylalanine, the second (tube Nos. 40-42) of ArgPro-Pro-Gly, the third (tube Nos. 51-58) of Arg-Pro-Pro-Gily-Phe-Ser-Pro-Phe-Arg (bradykinin) and the last (tube Nos. 59-61) of Scr-Pro-Phe-Arg, respectively. These results suggested that stem bromelain split bradykinin at two different bonds: Gly ${ }^{4}-$ Phe $^{5}$ and Phe ${ }^{5}-$ Ser $^{6}$, with the latter bond being more susceptible to the action of the enzyme. Hydrolysis on the amino-terminal side of phenylalanine at position 5 is a new finding, although hydrolysis on the carboxy-terminal side of this residue was previously reported $(1,5)$. In order to confirm the susceptibility of the Gly ${ }^{+}-P_{h} e^{5}$ bond of bradykinin, a pentapeptide, Arg-ProPro-Gly-Phe was digested. An aliquol of $2.75 \mathrm{mg}(4.8$ /moles) of the peptide, dissolved in $5 \mathrm{mM}$ phosphate buffer, $\mathrm{pH} 7.0$, was incubated with $1.5 \mathrm{mg}(0.045$, uncoles $)$ of freshly prepared enzyme in the presence of $2 \mathrm{mM}$, 3-mercaptoethanol at $37 \mathrm{C}$. Two-tenth milliliter aliquots of the reaction mixture were withdrawn at $0,1-, 6-$ and 24- hr incubation and deproteinized by adding two volumes of ethanol. After centrifugation at $6000 \mathrm{rpm}$ for $10 \mathrm{~min}$, the supernatant was submitled to paper electrophoresis with $0.1 \mathrm{M}$ pyridine- $0.1 \mathrm{M}$ acetic acid, $\mathrm{pH}$ 4.75. The reaction products were located by ninhydrin reaction. As shown in Fig. 1, the yields of the fastest and slowest components were found to increase with increasing incubation

TABLF ! Amino acid composition of the four main fractions from bromelain-digested bradykinin separated by Amberlite CG-50 chromatography

\begin{tabular}{lccccc}
\hline Fractions & Arg & Pro & Gly & Phe & Ser \\
I (tube Nos. 6 8) & - & -- & - & 0.210 & - \\
II (tube Nos. 40-42) & 0.190 & 0400 & 0.210 & - & - \\
III (tube Nos. 51-58) & 0.198 & 0.341 & 0.070 & 0.220 & 0.099 \\
IV (tube Nos. 59-61) & 0.145 & 0.198 & 0.017 & 0.187 & 0.132 \\
\hline
\end{tabular}




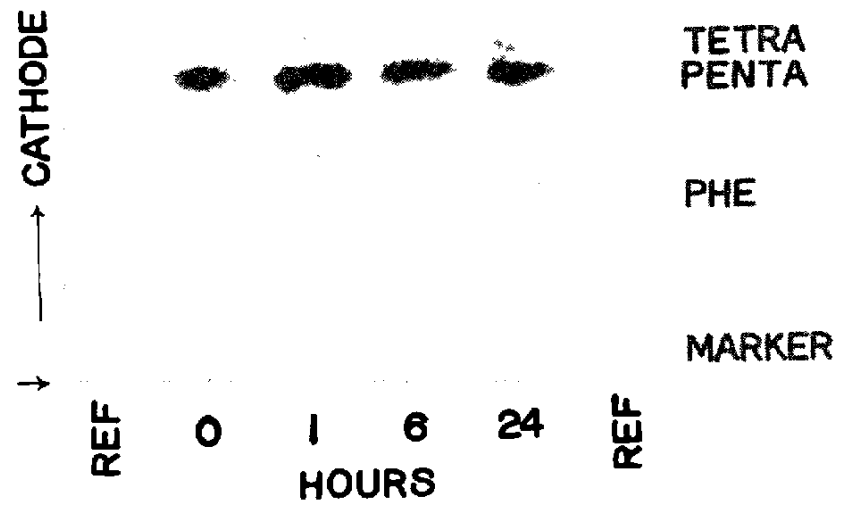

FIG. 1 Electrophoresis pattern of a reaction mixture of Arg-Pro-Pro-Gly-Phe with stem bromelain. Electrophoresis was carried out after deprotcinization by ethanol. REF: phenylalanine (PHE) and pentapeptide (PENTA), TETRA: tetrapeptide and MARKER: indigotetrasulfonic acid. The small arrow indicates the sample origin.

time. Amino acid analysis of each component indicated that the fastest band was composed of Arg-Pro-Pro-Gly and the slowest of Phe, both of which were released by the action of stem bromelain. The main band was identified as the undigested pentapeptide.

The results obtained in this study clearly indicate that stem bromelain splits bradykinin at two positions: $\mathrm{Phe}^{5}-\mathrm{Ser}^{6}$ and Gly $\mathrm{y}^{4} \mathrm{Phe}^{5}$, with the former bond being more susceptible.

Arg-Pro-Pro-Gly-Phe-Ser-Pro-Phe-Arg

The kininase activity may possibly have some relation to the anti-inflammatory activity of the enzyme.

Acknowledgements: The authors are grateful to Prof. M. Yamasaki of Tokyo University and Prof. T. Shigei of Nagoya University for pertinent advice and encouragement. Pentapeptide was kindly provided by Prof. K. Suzuki of Tohoku Pharm. Coll.. Gratitude is also due to Miss N. Seta for excellent technical assistance.

\section{REFERENCES}

1) Enomoto, T., Minesilita, S., Oh-ishi, S. and Shigei, T.: Japan. J. Phamacol. 17, 591 (1967);

2) Frafnkel-Conrat, H., Harris, J.I. And I.tvy, A.I.: Methods of Biochem. Anat. 2, 359 (1955);

3) Ando, T., Abukumagawa, E., Nagal, Y. and Yamasaki, M.: J. Biochem., Tokyo 44, 191 (1957): 4) Sakaguchi, S.: J. Biochem. Tokyo 5, 25 (1925): 5) Murachi, T. and MiYake, T. : Physiol. Chem. Phys. 2, 97 (1970) 